\title{
DETECTION OF CHANGE IN VEGETATION COVER USING MULTI-SPECTRAL AND MULTI-TEMPORAL INFORMATION FOR DISTRICT SARGODHA, PAKISTAN
}

\section{Detecção de alteração na cobertura vegetal com uso de informação multiespectral e multitemporal para o Distrito de Sargodha, Paquistão}

Farooq Ahmad

Department of Geography, University of the Punjab Lahore, Pakistan

f.ahmad@sheffield.ac.uk

Artigo recebido em 02/08/2012 e aceito para publicação em 14/09/2012

ABSTRACT: Detection of change is the measure of the distinct data framework and thematic change information that can direct to more tangible insights into underlying process involving land cover and landuse changes. Monitoring the locations and distributions of land cover changes is important for establishing links between policy decisions, regulatory actions and subsequent landuse activities. Change detection is the process that helps in determining the changes associated with landuse and land cover properties with reference to geo-registered multi-temporal remote sensing information. It assists in identifying change between two or more dates that is uncharacterized of normal variation. After image to image registrations, the normalized difference vegetation index (NDVI), the transformed normalized difference vegetation index (TNDVI), the enhanced vegetation index (EVI) and the soil-adjusted vegetation index (SAVI) values were derived from Landsat ETM+ dataset and an image differencing algorithm was applied to detect changes. This paper presents an application of the use of multi-temporal Landsat ETM+ images and multi-spectral MODIS (Terra) EVI/NDVI time-series vegetation phenology metrics for the District Sargodha. The results can be utilized as a temporal land use change model for Punjab province of Pakistan to quantify the extent and nature of change and assist in future prediction studies. This will support environmental planning to develop sustainable landuse practices.

Keywords: Change detection, EVI, Landsat, multi-temporal, multi-spectral, NDVI, Pakistan

RESUMO: Detecção de alterações é uma medida especifica de enquadramento e informações temáticas que pode direcionar percepções mais tangíveis na compreensão do processo de mudanças na cobertura vegetal e uso do solo. Monitorar as localizações e as distribuições das mudanças na cobertura do solo é processo significativo para estabelecer ligações entre decisões políticas, ações reguladoras e as posteriores atividades de uso. A detecção de alterações auxilia na determinação de mudanças associadas ao uso e cobertura do solo tendo como referência informações multitemporais através de sensoriamento remoto. Ela auxilia na identificação de alterações entre dois ou mais dados diferentes da variação normal. Este artigo apresenta uma aplicação do uso de imagens multi-temporais Landsat ETM + e imagens multi-espectrais do MODIS (Terra) EVI / NDVI em séries temporais para avaliação da fenologia da vegetação no Distrito de Sargodha (Paquistão). Os resultados podem ser utilizados como um modelo para as alterações temporais do uso do solo na província de Punjab, Paquistão, para quantificar a extensão e a natureza das mudanças e auxiliar em estudos futuros de predição. Tal ferramenta dá suporte ao planejamento ambiental para o desenvolvimento de práticas sustentáveis de uso do solo.

Palavras-chave: detecção de alterações, EVI, Landsat multi-temporal, multi-espectral, NDVI, Paquistão 


\section{INTRODUCTION}

Assessing and monitoring the state of the earth surface is a key requirement for global change research (NRC, 1999; LAMBIN et al., 2001; JUNG et al., 2006; XIE, 2008). Classifying and mapping vegetation is an important technical task for managing natural resources as vegetation provides a base for all living beings and plays an essential role in affecting global climate change (XIAO et al., 2004; XIE, 2008). Vegetation extraction from remote sensing imagery is the process of extracting vegetation information by interpreting satellite images based on the interpretation elements and association information (XIE, 2008).
Preprocessing of satellite images prior to vegetation extraction is essential to remove noise (SCHOWENGERDT, 1983) and increase the interpretability of image data (CAMPBELL, 1987; SCHOWENGERDT, 2006). The ideal result of image preprocessing is that all images after image preprocessing should appear as if they were acquired from the same sensor (HALL et al., 1991; Xie, 2008). Image preprocessing commonly comprises a series of operations, including but not limited to bad lines replacement, radiometric correction, geometric correction, image enhancement and masking although variations may exist for images acquired by different sensors (SCHOWENGERDT, 1983; CAMPBELL, 1987; XIE, 2008).

Figure 1. District Sargodha - Landsat ETM+ 1999 mosaic image.

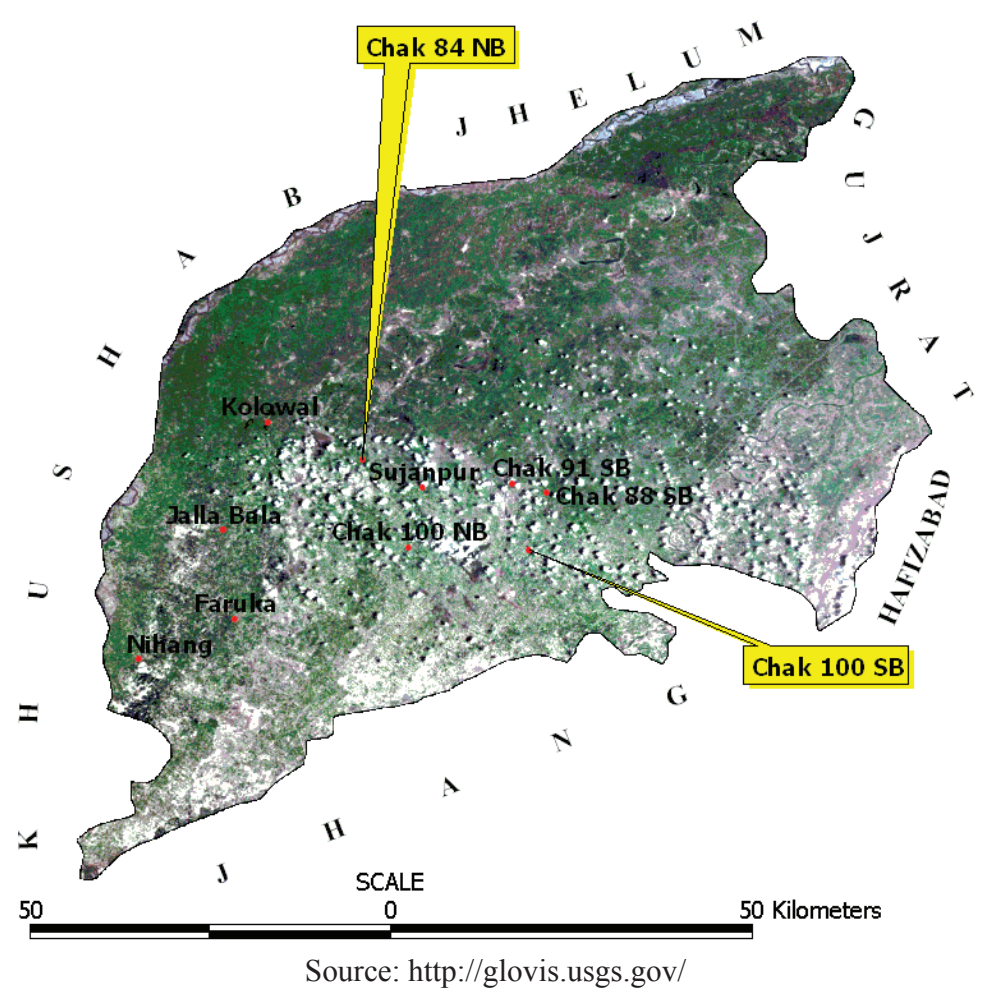

Change detection as defined by Hoffer (1978) is temporal effects as variation in spectral response involves situations where the spectral characteristics of the vegetation or other cover type in a given location change over time. Singh (1989) described change detection as a process that observes the differences of an object or phenomenon at different times (ADIA; RABIU, 2008). Land cover composition and change are important factors that affect ecosystem condition and function (JONES et al., 1997; LUNETTA et al., 2006). Extraction of land cover maps for mapping surface composition and assessment of changes in surface cover composition over time are requirements common to each investigation. Applied remote sensing became more and more inevitable technology contributing to human's progress toward sustainability by 
support solving environment related tasks on local, regional and global level (ZORAN; ANDERSON, 2006). Moreover, regularly acquired satellite data may be used for long-term surveillance of certain features (AUBREY et al., 1996; ZORAN; ANDERSON, 2006). These data acquired by optical, infrared and microwave sensors yield information on chlorophyll content, the surface temperature, turbidity, hydrocarbon load respectively (ZORAN; ANDERSON, 2006).

A remote sensing sensor is a key device that captures data about an object or scene remotely. Since objects have their unique spectral features, they can be identified from remote sensing imagery according to their unique spectral characteristics (XIE, 2008). A good case in vegetation mapping by using remote sensing technology is the spectral radiances in the red and near-infrared (NIR) regions, in addition to others. The radiances in these regions could be incorporated into the spectral vegetation indices (VI) that are directly related to the intercepted fraction of photosynthetically active radiation (ASRAR et al., 1984; GALIO et al., 1985; XIE, 2008). The spectral signatures of photosynthetically and non-photosynthetically active vegetation showed obvious difference and could be utilized to estimate forage quantity and quality of grass prairie (BEERI et al., 2007; XIE, 2008).

\section{Study Area}

The District Sargodha (Figure 1) is located in the Northeast of Pakistan between $31^{\circ} 34^{\prime}$ and $32^{\circ} 36^{\prime}$ North latitude and $72^{\circ} 10^{\prime}$ and $73^{\circ} 18^{\prime}$ 'East longitude (GOP, 1999), mainly comprises flat, fertile plains although a few small Kirana Hills exist along Sargodha-Faisalabad road. The River Jhelum flows on the northern and western, and the River Chenab lies on the eastern side of the district.

\section{DATA AND METHODOLOGY}

This paper focuses on the comparisons of popular remote sensing sensors, commonly adopted image processing methods and prevailing classification accuracy assessments. The basic concepts, available imagery sources and classification techniques of remote sensing imagery related to vegetation mapping were introduced, analyzed and compared (XIE, 2008). The advantages and limitations of using remote sensing imagery (SCHOWENGERDT, 1983; CAMPBELL, 1987; SCHOWENGERDT, 2006) for vegetation cover mapping were provided to iterate the importance of thorough understanding of the related concepts and careful design of the technical procedures, which can be utilized to study vegetation cover from remote sensed images (XIE, 2008).

Remote sensing imagery offer unique possibilities for spatial and temporal characterization of the changes. The basic requirement is the availability of different dates of imagery which permits continuous monitoring of change and environmental developments over time (AYMAN; ASHRAF, 2009). Change detection can be performed by restricting the analysis to a single sensor series or by using different satellite datasets. Two Landsat ETM+ scenes 1999 and 2002 for District Sargodha (path 150, row 37 and 38) were used to implement the vegetation indices. ERDAS Imagine and ENVI software have been used to generate the false colour composite by combining the near infrared, red and green bands (4, 3, 2 respectively) for Landsat ETM+ images. This was carried out for vegetation recognition, because chlorophyll in plants reflects very well for the near-infrared (NIR) band compared to the visible band of the electromagnetic spectrum (Hatfield et al., 1984). Vegetation indices were applied upon 1999 and 2002 ETM+ images and further change detection technique was used to develop the EVI, SAVI, NDVI and TNDVI maps.

In order to use these two scenes, several steps were followed to prepare for an accurate extraction and detection. These vital steps are: image registration, image enhancement and image mosaic as discussed by Macleod and Congalton (1998), Mahmoodzadeh (2007) and Al-Awadhi et al., 2011. These scenes were corrected and geo-referenced using projection UTM, zone 43 and datum WGS 84.

Methods incorporated in this research paper included the application of an automated MODIS (Terra) EVI/NDVI time series to support multi-temporal imagery analysis. MODIS (Terra) EVI/NDVI data preprocessing was conducted to provide a filtered and cleaned uninterrupted data stream to support multi-temporal or phenological analysis (MODIS, 1999). 
MODIS (Terra) EVI/NDVI 16-days composite grid data in HDF format were acquired between February 2000 and February 2010 from the NASA Earth Observing System (EOS) data gateway. Details documenting the MODIS (Terra) EVI/NDVI compositing process and Quality Assessment Science Data Sets can be found at NASA's MODIS web site (MODIS, 1999; USGS, 2008).

In this research paper (Figure 2), Landsat products have been applied for vegetation change detection assessment. Since Landsat has a long history of dataset, it is very helpful to map long-term vegetation cover and study the spatio-temporal vegetation changes (SCHROEDER et al., 2006; XIE, 2008). Landsat TM images, striding a long period of time from 1986 to 2002, were used to conduct quantitative analyses of wetland landscape patterns and their dynamic changes in the estuary of the Minjiang River (ZHENG et al., 2006; XIE, 2008). Because of the different characteristics of spectral sensors in the Landsat image series, it is necessary to correct the spectral reflectance between images acquired by those sensors. This is especially necessary in long-term vegetation cover monitoring research where either Landsat TM or ETM+ images are used (Xie, 2008).

Spectral-based change detection techniques have tended to be performance limited in biologically complex ecosystems due, in larger part, to phenology-induced errors (LUNETTA et al., 2002; LUNETTA et al., 2002a; LUNETTA et al., 2006). An important consideration for land cover change detection is the nominal temporal frequency of remote sensor data acquisitions required to adequately characterize change events (LUNETTA et al., 2004; LUNETTA et al., 2006). Ecosystem-specific regeneration rates are an important consideration for determining the required frequency of data collections to minimize errors. As part of the natural processes associated with vegetation dynamics, plants undergo intra-annual cycles. During different stages of vegetation growth, plant structures and associated pigment assemblages can vary significantly (LUNETTA et al., 2006).

Figure 2. Scheme for data and methodology

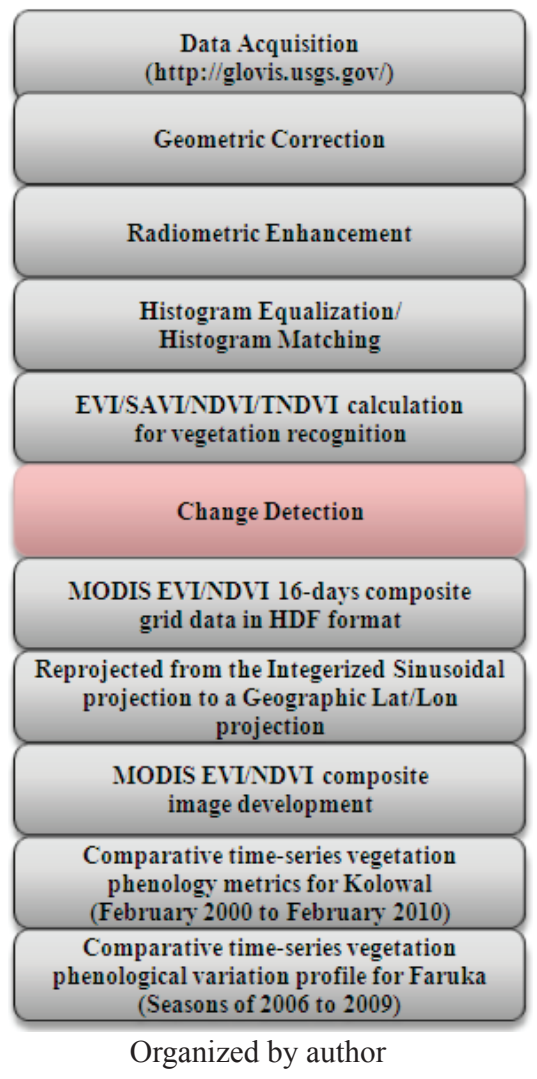

Soc. \& Nat., Uberlândia, ano 24 n. 3, 557-572, set/dez. 2012 


\section{Approach to generating the measurement}

Vegetation Indices are seamless data products that are computed from the same mathematic formulae across all pixels in time and space, without prior assumptions of biome type, land cover condition, or soil type and thus represent actual, long-term measurements of the land surface (HUETE et al., 2002). The VI product works optimally with cloud filtering, radiometric calibration, precise geolocation, and a snow mask. In addition, the product performs best using top-of-canopy reflectance inputs, corrected for atmospheric ozone, molecular scattering, aerosol, and water vapour (HUETE et al., 2006). Hyperspectral vegetation research is still based on multi-spectral indices used as reference or contemporary data. These indices are readily adaptable to hyperspectral data but remain problematic in arid and semi-arid areas (BROGE et al., 2000; MCWIRE et al., 2000; FRANK; MENZ, 2003). Hyperspectral data could provide much more possibilities compared with multi-spectral data in detecting and quantifying sparse vegetation because it provides a continuous spectrum across a range in wavelengths (KUMAR et al., 2001; FRANK; MENZ, 2003).

\section{RESULTS}

Figure 3 shows change detection using EVI model. Landsat ETM+ images for 1999 and 2002 were used to extract temporal changes in District Sargodha. For balancing of an image, the geometric correction, radiometric enhancement, histogram equalization and histogram matching techniques were applied using ERDAS imagine software. The EVI model was applied upon Landsat ETM + 1999 and 2002 images and further change detection technique was used for extraction of land cover changes. The finding showed that during the period 1999 and 2002, increased vegetation and decreased vegetation percentage was same, while some increase $>$ some decrease in district Sargodha (Figure 3 and Table 1). The result showed that the district Sargodha has a potential for agricultural enhancement especially in the areas adjacent to district Hafizabad and Gujrat, while western part of district Sargodha and adjacent to district Khushab, soil productively was decreasing.

Figure 4 shows change detection using SAVI model. For this experiment, Landsat ETM+ images for 1999 and 2002 were used. After geometric correction, SAVI model was applied upon ETM+ images and further change detection technique was used for extraction of potential agricultural sites in district Sargodha. The result showed that increased $>$ decreased and some increase $>$ some decrease. The SAVI model showed better performance than the EVI. The finding showed that central, northeastern and eastern part of the district has a great potential for agricultural enhancement, while the soil productively is lesser in southeastern and western part of district Sargodha. The value of $L$ varies by the amount or cover of green vegetation: in very high vegetation regions, $\mathrm{L}=0$; and in areas with no green vegetation, $\mathrm{L}=1$. Generally, an $\mathrm{L}=0.5$ works well in most situations and is the default value used (HUETE, 1988). The SAVI is computed following the equation:

$$
\mathrm{SAVI}=(1+\mathrm{L})^{*}(\mathrm{NIR}-\mathrm{R}) /(\mathrm{NIR}+\mathrm{R}+\mathrm{L})
$$

Rondeaux et al., 1996 introduced another model known as Optimized Soil-Adjusted Vegetation Index (OSAVI). The OSAVI is computed following the equation:

$$
\text { OSAVI }=(\mathrm{NIR}-\mathrm{R}) /(\mathrm{NIR}+\mathrm{R}+0.16)
$$

The value $\mathrm{L}=0.16$ appears to be the optimum adjusting factor for the SAVI family of indices. The OSAVI (RONDEAUX et al., 1996) corresponds, in fact, to the Transformed Normalized Difference Vegetation Index (TSAVI) with the parameters $\mathrm{a}=1$ and $\mathrm{b}=0$, and is therefore not equivalent to the Normalized Difference Vegetation Index (NDVI). 
Figure 3. Map showing change detection using EVI model.

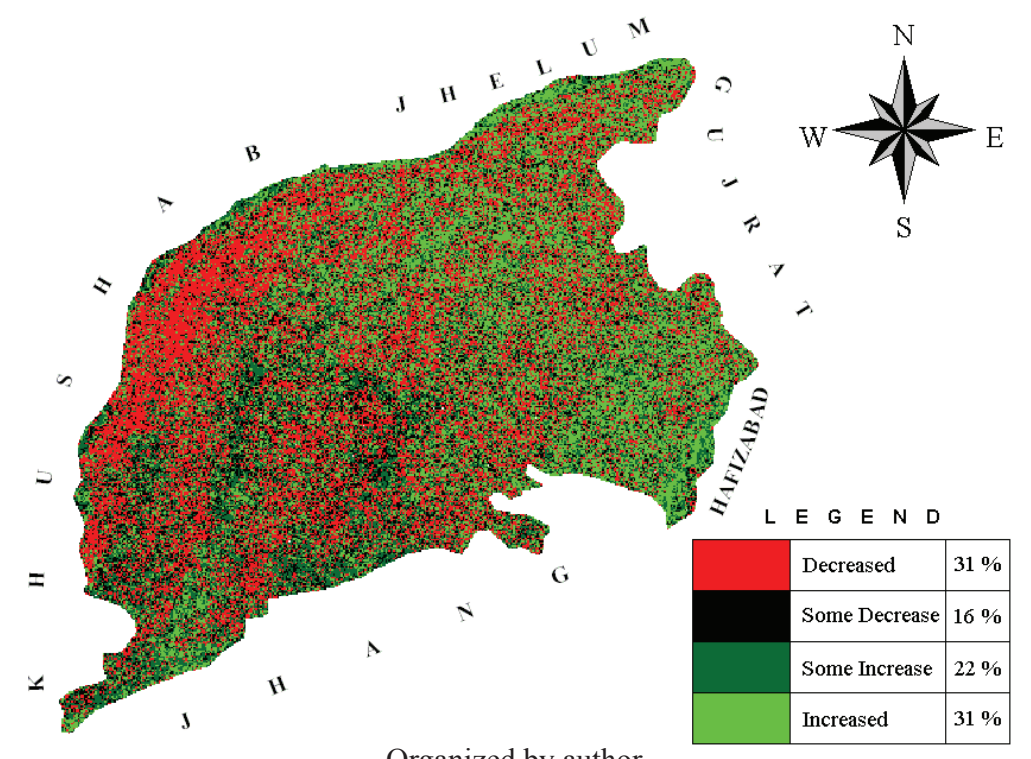

Organized by author.

Figure 4. Map showing change detection using SAVI model

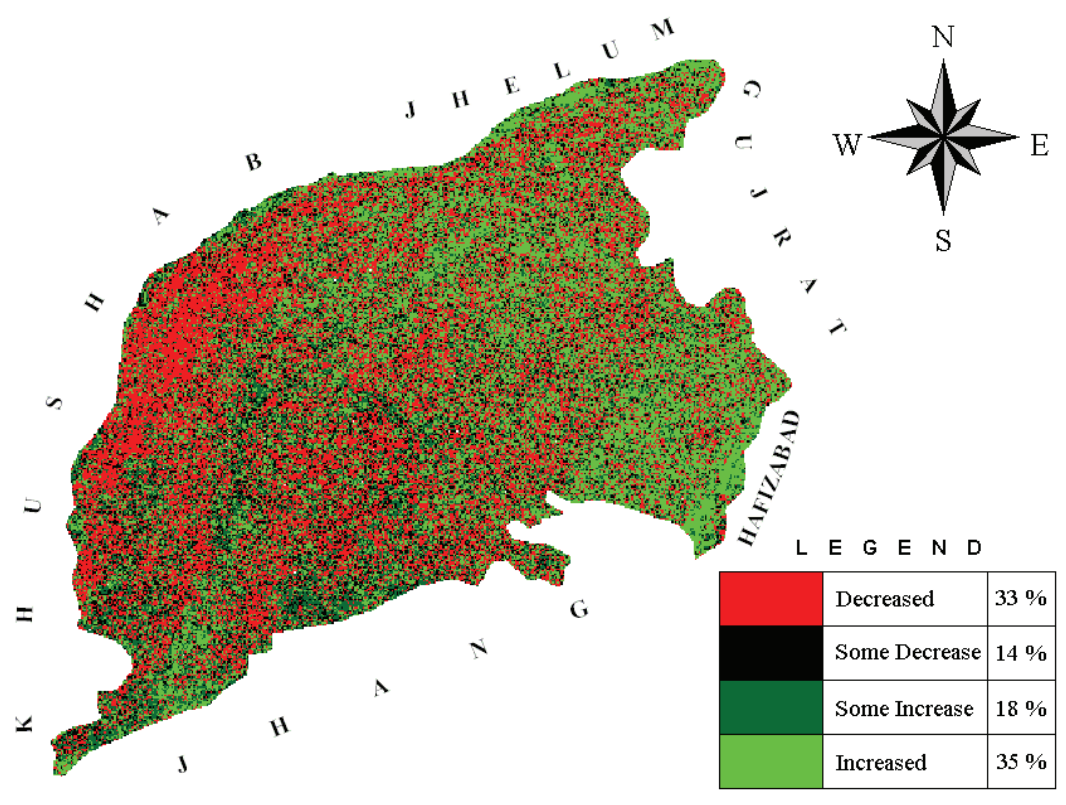

Organized by author.

Figure 5 shows change detection using NDVI model. In this experiment SAVI=NDVI (HUETE, 1988). When $\mathrm{L}=0$ makes SAVI equivalent to NDVI (HUETE, 1988; RONDEAUX et al., 1996). The NDVI (USGS (2010) approach is based on the fact that healthy vegetation has low reflectance in the visible portion of the EMS due to chlorophyll and other pigment absorption and has high reflectance in the NIR because of the internal reflectance by the mesophyll spongy tissue of green leaf. The NDVI can be calculated as a ratio of red and the NIR bands of a sensor system (HUETE, 2005). The NDVI is related to the absorption of photosynthetically active radiation and basically measures the photosynthetic capability of leaves, which is related to vegetative canopy resistance and water vapour transfer (WAN, 2003). 
Figure 5. Map showing change detection using NDVI model

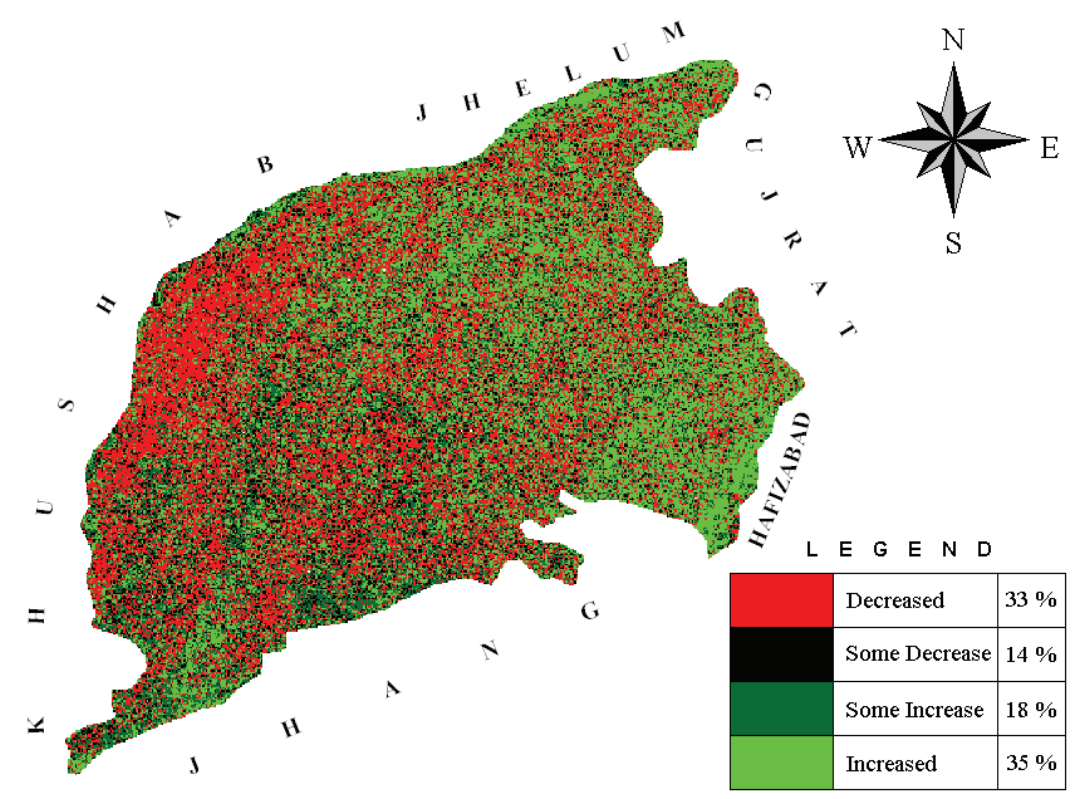

Organized by author.

Figure 6 shows change detection using TNDVI model. After geometric correction, TNDVI model was applied upon ETM+ 1999 and 2002 images and further change detection technique was used for extraction of soil potential sites in district Sargodha. The finding showed that increased $>$ decreased and further some increase $>$ some decrease. The TNDVI represents the vegetation biomass and is expressed as the ratio of near-IR reflection to red reflection (Tucker, 1979). Greenland (1994) expresses TNDVI as "an integrated function of photosynthesis, leaf area and evapotranspiration".

Table 1. Vegetation matrix percentage for individual change classification.

\begin{tabular}{|l|c|c|c|c|l|}
\hline $\begin{array}{c}\text { Vegetation } \\
\text { Indices }\end{array}$ & $\begin{array}{c}\text { Decreased } \\
(\%)\end{array}$ & $\begin{array}{c}\text { Some Decrease } \\
(\%)\end{array}$ & $\begin{array}{c}\text { Some Increase } \\
(\%)\end{array}$ & \multicolumn{1}{|c|}{ Reference } \\
\hline EVI & 31 & 16 & 22 & 31 & $\begin{array}{l}\text { Liu and Huete, } 1995 \\
\text { Justice et al., } 1998\end{array}$ \\
\hline SAVI & 33 & 14 & 18 & 35 & Huete, 1988 \\
\hline NDVI & 33 & 14 & 18 & 35 & Rouse et al., 1973 \\
\hline TNDVI & 22 & 25 & 29 & 24 & Tucker, 1979 \\
\hline
\end{tabular}

Organized by author. 
Figure 6. Map showing change detection using TNDVI model.

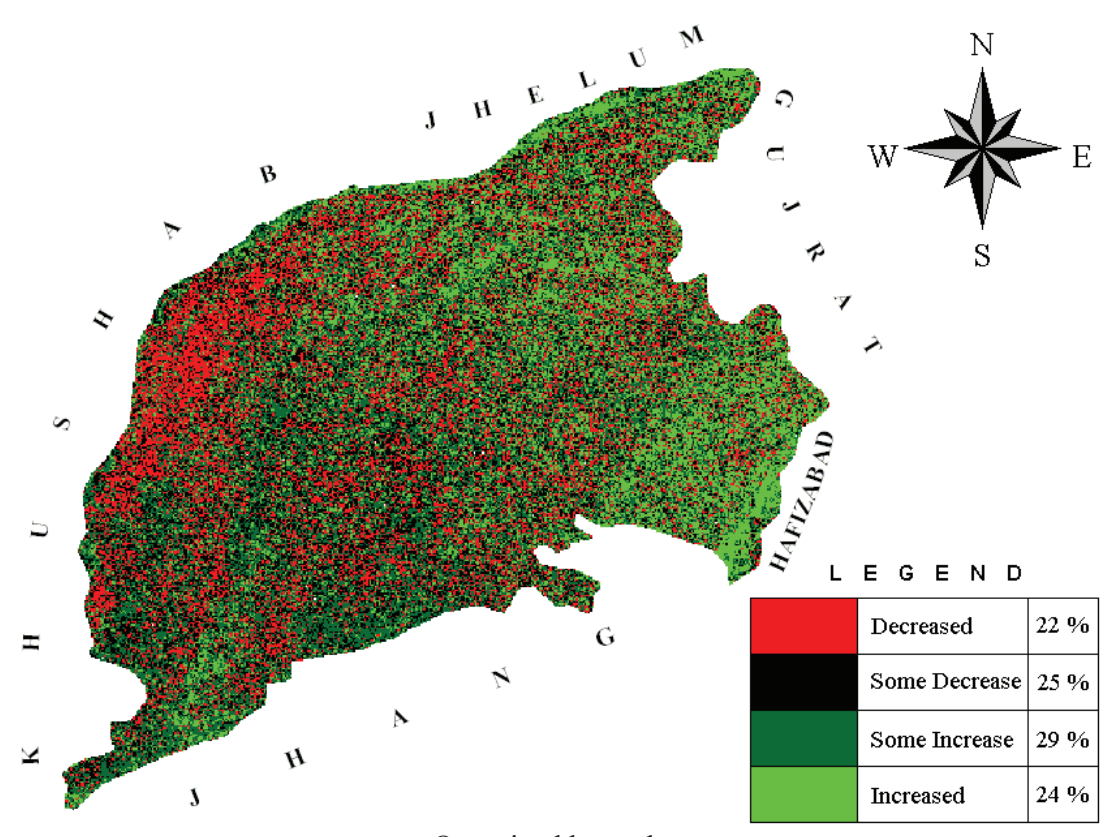

Organized by author.

Figure 6. Map showing change detection Figure 7 shows comparative analysis of vegetation indices. The modeling process is effective to estimate land cover from satellite images, even using a limited number of data (BOCCO et al., 2007). The EVI is an 'optimized index' designed to enhance the vegetation signal with improved sensitivity in high biomass regions and improved vegetation monitoring through a de-coupling of the canopy background signal and a reduction in atmosphere influences (LIU; HUETE, 1995; JUSTICE et al., 1998; HUETE et al., 1999).

Figure 7. Comparative analysis of vegetation indices.

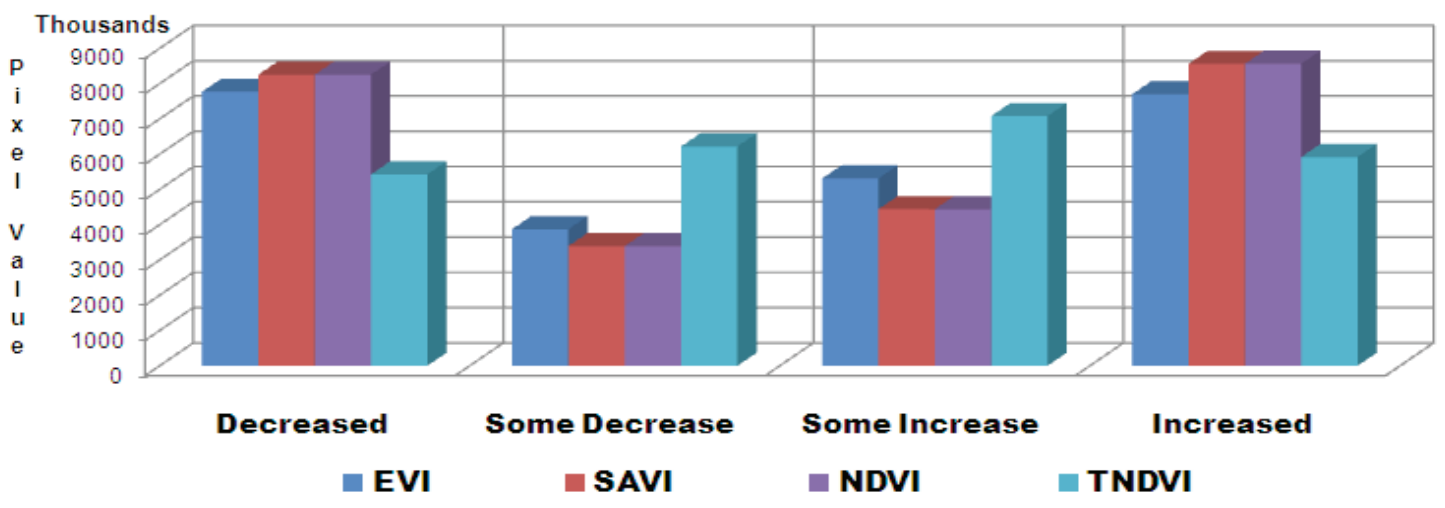

Organized by author.

Figure 8 shows comparative time-series vegetation phenology metrics for Kolowal district Sargodha. In this vegetation phenology metrics EVI (Terra) $500 \mathrm{~m}$ and NDVI (Terra) $500 \mathrm{~m}$ data products for the seasons of 2000 to 2010 at 16-days interval have been evaluated for green cover fraction and biomass at the same location. The result showed that EVI differs from NDVI by attempting to correct for atmospheric and background effects. The EVI appears to be superior in discriminating subtle differences in 
areas of high vegetation density, situations in which NDVI tends to saturate. The NDVI has been used for several decades, which is advantageous for studying historical changes (TRISHCHENKO et al., 2002). The EVI is a good indicator of the phenology of the land cover types, the research tested the contribution of EVI data to the land cover classification. Comparative time-series vegetation phenology metrics showed that climate was stable (start/end) and land degradation can't be seen during the seasons of 2000 to 2010 . Variation in biomass and soil productivity can be seen due to summer monsoon and winter depression.

Figure 9 shows comparative time-series vegetation phenological variation profile for Faruka district Sargodha. In this vegetation index EVI (Terra) $250 \mathrm{~m}$ data product for the period 2006 to 2009 at 16-days interval have been evaluated for green cover fraction and biomass at the same location. The result showed that vegetation potential increased due to winter depression and summer monsoon. The impact of winter depression was stronger as compared to summer monsoon in district Sargodha. The climate was stable during the period 2006 to 2009 and land degradation can't be seen.

Phenology is the study of the times of recurring natural phenomena. One of the most successful of the approach is based on tracking the temporal change of a vegetation index such as NDVI or EVI. The evolution of vegetation index exhibits a strong correlation with the typical green vegetation growth stages. The results (temporal curves) can be analyzed to obtain useful information such as the start/end of vegetation growing season (GAO; MAS, 2008).

Figure 8. Comparative time-series vegetation phenology metrics for Kolowal, District Sargodha.

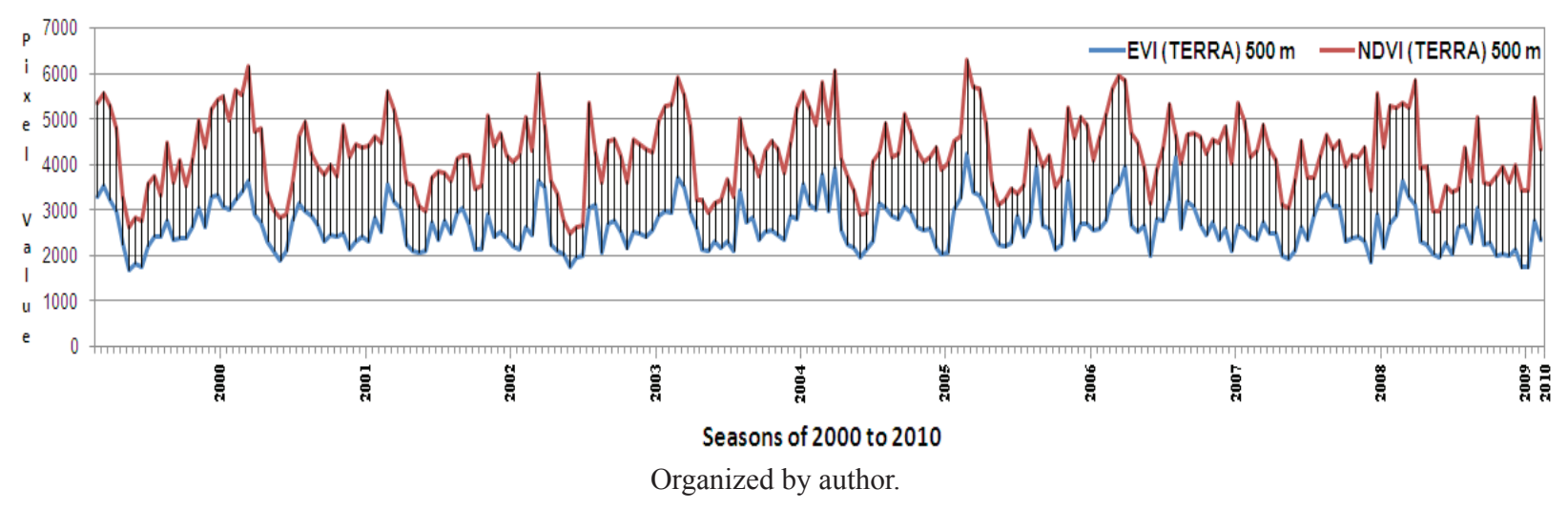

Figure 9. Comparative time-series vegetation phenological variation profile for Faruka, District Sargodha.

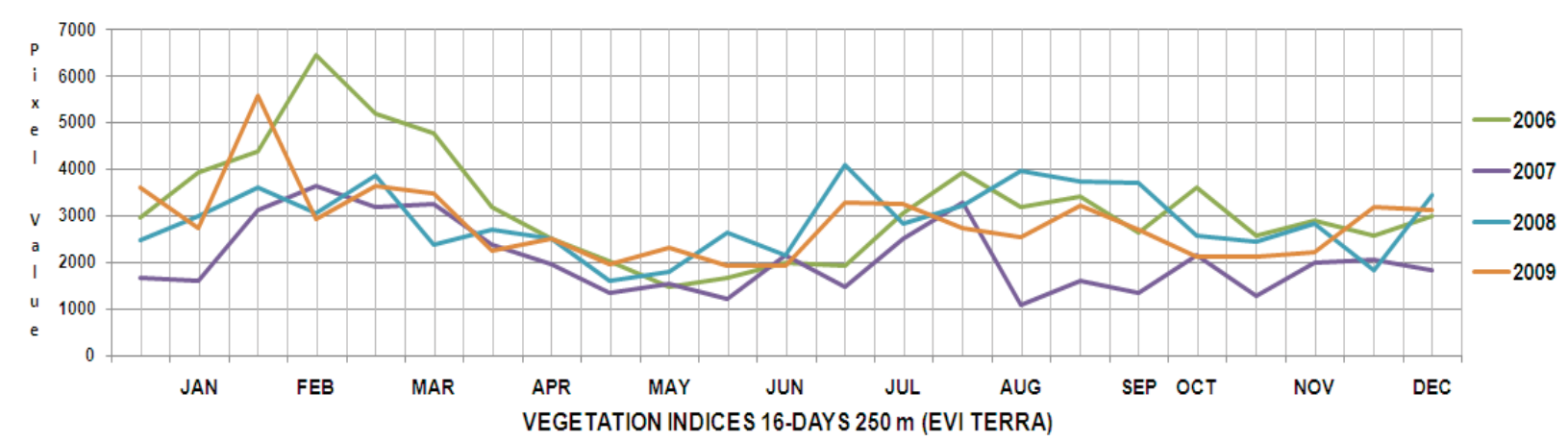

Organized by author. 
Figure 10 and 11 shows horizontal and vertical profile for Faruka district Sargodha. The profiles have been generated using ENVI software. Both the profile shows the variation in green cover fraction and biomass but showed that productivity was stable (start/ end) and climatic variation can't be seen at this location. Pixel based digital extraction is the best technique for monitoring of climatic variation and vegetation stress. Hyperspectral imaging (KRUSE, 1988) is a new technique in remote sensing that generates hundreds of spectral bands at different wavelength channels for the same area (ASPINALL, 2002). In recent years, several efforts have been directed towards the incorporation of high performance computing models (GREEN et al., 1988; HARSANYI; CHANG, 1994; ASPINALL et al., 2002) in remote sensing missions (ASPINALL et al., 2002; MARCUS, 2002).

Figure 10. Horizontal profile for Faruka.

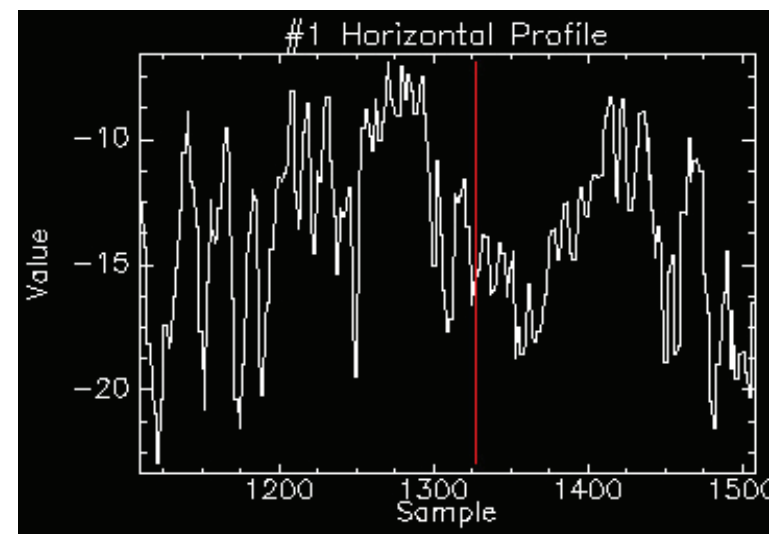

Figure 11. Vertical profile for Faruka.

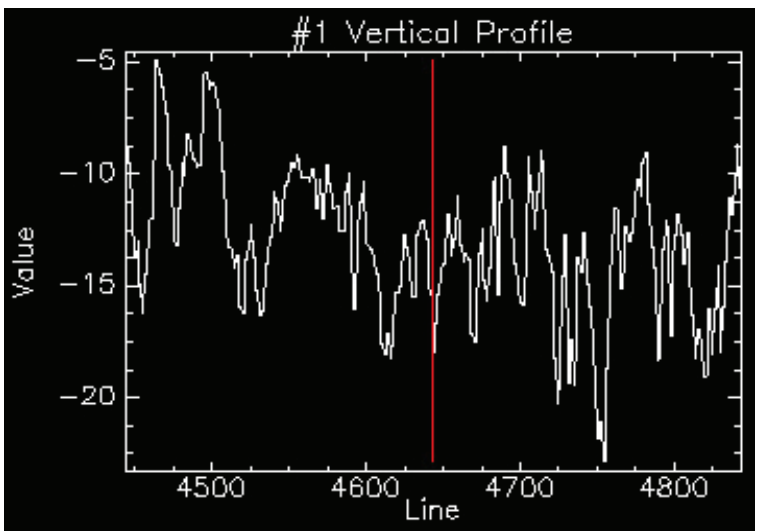

\section{DISCUSSION AND CONCLUSIONS}

The availability of no-cost MODIS (Terra) EVI/NDVI data (MODIS, 1999) and new automated data processing techniques that provide high-quality continuous time series data represent a major advancement for the automated monitoring annual land cover change and vegetation condition. Major advantages of the EVI/NDVI based change detection approach presented in this research paper include (i) robust results, (ii) nominal computational requirements, (iii) automated data processing protocols, (iv) annual change alarm product capability, and (v) rapid product delivery (Lunetta et al., 2006). The importance of quantifying change omission errors is critical to the development of a robust assessment of change detection 
performance. It was shown that the multi-temporal and multi-sensor satellite data have a great success in biomass analysis (AKKARTALA et al., 2004).

Remote sensing change detection techniques can be broadly classified as either pre or post classification change methods. Pre-classification methods can further be characterized as being spectral or phenology based (LUNETTA et al., 2006). The phenology metrics showed a clear relationship with the seasonality of rainfall, winter and summer growing seasons (WESSELS et al., 2011).

When describing RS data it is useful to do so in terms of spatial, spectral, temporal, and radiometric resolution (JENSEN, 1996; PRENZEL, 2004). Collectively, these describe the most important features of RS data. Technological constraints associated with the sensor and platform have a large bearing on how these resolutions manifest themselves as part of the data. For satellite-based RS data, at least two key 'tradeoffs' emerge from these underlying technological challenges (PRENZEL, 2004). One of the most important is that generally, the higher the spatial resolution, the lower the spatial coverage. This dramatically limits the breadth over which a particular change analysis can be conducted (SCHOWENGERDT, 1983; SCHOWENGERDT, 2006). The second important tradeoff is that the smaller the coverage, typically the longer the re-visitation time. This is important when RS data is required frequently (CAMPBELL, 1987). Although there are other tradeoffs, these two are the most significant for change analysis studies. High-spatial resolution satellite systems have adopted pointable optics to compensate for the long periods of time required to revisit the same orbit track (PRENZEL, 2004).

Landsat ETM+ different bands have used in order to estimate the vegetation quantities parameter based on vegetation indices. The gained result showed significant correlations between ETM + bands and vegetation groups such as grasses, forbs, shrubs, and bushy trees (SOLAIMANI et al., 2011). The NDVI is the most commonly used of all the VIs tested and its performance, due to non-systematic variation as described by Huete and Liu (1994) and Liu and Huete (1995). The soil background is a major surface component controlling the spectral behaviour of vegetation canopies and on which the retrieval of biophysical characteristics of the canopy depends. Although vegetation indices, such as the soil-adjusted (HUETE, 1988) vegetation indices, considerably reduce these soils effects, estimation of the vegetation characteristics from the indices still suffers from some imprecision, especially at relatively low cover, if no information about the target is known (RONDEAUX et al., 1996). This study focuses on change detection on pixel based methods using multi-temporal and multi-spectral images. Initial experimental results indicate that, the proposed indices perform sufficiently well in detecting changes on the test dataset.

\section{ACKNOWLEDGEMENTS}

The author wishes to thank respected Dr. Michael Steven, Professor of Environmental Remote Sensing, School of Geography, University of Nottingham Malaysia Campus, Selangor, Malaysia for review and providing valuable comments on draft-version of this paper.

\section{REFERENCES}

ADIA, S. O., RABIU, A. B. Change detection of vegetation cover, using multi-temporal remote sensing data and GIS techniques. Proceedings of Map India, 6-8 February 2008. URL: http://gisdevelopment.net/ application/environment/ffm/adia.htm. Accessed on September 16, 2011.

AKKARTALA, A.; TÜRÜDÜA, O.; ERBEKB, F. $S$. Analysis of changes in vegetation biomass using multitemporal and multisensor satellite data. XXXV ISPRS Congress, 12-23 July 2004, Istanbul, Turkey. Proceedings... URL: http://www.isprs.org/proceedings/XXXV/congress/yf/papers/946.pdf. Accessed on September 17, 2011.

AL-AWADHI, T.; AL-SHUKILI; A., AL-AMRI, Q. The use of remote sensing \& geographical information systems to identify vegetation: The case of Dhofar Governorate (Oman). URL: http://www.isprs.org/ proceedings/2011/ISRSE-34/211104015Final00239. pdf. Assessed on September 10, 2011. 
ASPINALL, R. J. Use of logistic regression for validation of maps of the spatial distribution of vegetation species derived from high spatial resolution hyperspectral remotely sensed data. Ecological Modelling, 157: 301-312. 2002.

ASPINALL R. J., MARCUS W.A., BOARDMAN J.W. Considerations in collecting, processing, and analyzing high spatial resolution hyperspectral data for environmental investigations. Journal of Geographical Systems, 4: 15-29. 2002.

ASRAR, G., FUCH, M.; KANEMASU; E. T. Estimating absorbed photosynthetic radiation and leaf area index from spectral reflectance in wheat. Agronomy Journal, 76: 300-306. 1984.

AUBREY, D; MONCHEVA, S.; DEMIROV, E.; DIACONU, V.; DIMITROV, A. Environmental changes in the Western Black Sea related to anthropogenic and natural conditions. Journal of Marine Systems, 7(2-4): 411-425. 1996 (doi: 10.1016/0924-7963(95)00031-3)

AYMAN HN, ASHRAF KH. Integration of Misrsat-1 and SPOT-2 data for quantitative change detection applications. ICGST-GVIP Journal, 9(5): 53-59. 2009.

BEERI, O.; PHILLIPS, R.; HENDRICKSON, J. Estimating forage quantity and quality using aerial hyperspectral imagery for northern mixed-grass prairie. Remote Sensing of Environment, 110: 216-225. 2007.

BOCCO, M.; OVANDO, G.; SAYAGO, S.; WILLINGTON, E. Neural network model for land cover classification from satellite images. Agricultura Técnica, 67(4): 414-421. 2007. (doi: 10.4067/S036528072007000400009)

BROGE, N. H.; LEBLANC, E. Comparing prediction power and stability of broadband and hyperspectral vegetation indices for estimation of green leaf area index and canopy chlorophyll density. Remote Sensing of Environment, 76: 152-172, 2000.
CAMPBELL, J.B. Introduction to remote sensing. The Guilford Press: New York, 1987, p.281.

FRANK, M.; MENZ, G. Detecting seasonal changes in a semi-arid environment using hyperspectral vegetation indices. $3^{\text {rd }}$ EARSel Workshop on Imaging Spectroscopy, Herrschingen, Germany. Proceedings... of 13-16 May 2003, pp.504-512.

GALIO, K.P.; DAUGHTRY, C.S.T.; BAUER, M. E. Spectral estimation of absorbed photosynthetically active radiation in corn canopies. Agronomy Journal, 78: 752-756, 1985.

GAO, Y.; MAS, J. F. MODIS EVI as an ancillary data for an object-based image analysis with multi-spectral MODIS data. 2008. URL: http://www. isprs.org/proceedings/XXXVIII/4-C1/Sessions/ Session5/6590_YGao_Proc_poster.pdf. Accessed on September 07, 2011.

GOP. District census report of Sargodha 1998. Population Census Organization, Statistics Division, Government of Pakistan, Islamabad, Pakistan, 1999, p.1.

GREEN, A. A.; BERMAN, M.; SWITZER, P.; CRAIG, M. D. A transform for ordering multispectral data in terms of image quality with implications for noise removal. IEEE Transactions on Geoscience and Remote Sensing, 26(1), 1988, p.65-74.

GREENLAND D (1994). Use of satellite-based sensing in land surface climatology. Progress in Physical Geography, 18(1): 1994, p.1-15.

HALL, F. G.; STREBEL, D. E.; NICKESON; J. E.; GOETZ, S.J. Radiometric rectification: Toward a common radiometric response among multi-date, multi-sensor images. Remote Sensing of Environment, n.35, 1991, p. 11-27.

HARSANYI, J.C. ; CHANG, C. I. Hyperspectral image classification and dimensionality reduction: An orthogonal subspace projection approach. IEEE Transactions on Geoscience and Remote Sensing, n.32, 1994, p. 779-785. 
HATFIELD, J. L., ASRAR, G.; KANEMASU, E. T. Intercepted photosynthetically active radiation estimated by spectral reflectance. Remote Sensing of Environment, n.14, 1984, p. 65-75.

HOFFER, R. M. Biological and physical considerations in applying computer-Aided analysis techniques to Remote Sensor data, In Remote Sensing: The quantitative approach. Swam PH, Davis SM (Eds), McGraw- Hill, USA, pp.35-98, 1978.

HUETE, A. R. A soil adjusted vegetation index (SAVI). Remote Sensing of Environment, 25(3), 1988, p.295-309.

HUETE, A.R. Global variability of terrestrial surface properties derived from MODIS visible to thermal-infrared measurements. IGARSS $05 \mathrm{Ge}-$ oscience and Remote Sensing Symposium, 25-29 July 2005. Proceedings... http://ieeexplore.ieee.org/ iel5/10226/32601/01526782.pdf. Accessed on September 05, 2011.

HUETE, A. R, DIDAN, K., MIURA, T. Overview of the radiometric and biophysical performance of the MODIS vegetation indices. Remote Sensing of Environment, n.83, 2002, p. 195-213.

HUETE, A.R, HUEMMRICH, K.F., MIURA, T., XIAO, X.; DIDAN, K.; LEEUWEN VAN W.; HALL, F.; TUCKER, C. J. Vegetation Index greenness global data set: White Paper for NASA ESDR/CDR. 2006 . URL: http://landportal.gsfc.nasa.gov/Documents/ ESDR/VI_Huete_whitepaper.pdf. Assessed on October 12, 2011.

HUETE, A. R, JUSTICE, C.; LEEUWEN VAN W. MODIS vegetation index (MOD 13) algorithm theoretical basis document version 3. 1999. URL: http:// modis.gsfc.nasa.gov/data/atbd/atbd_mod13.pdf. Accessed on September 17, 2011.

HUETE, A. R.; LIU, H. Q. An error and sensitivity analysis of the atmospheric- and soil-correcting variants of the NDVI for the MODIS-EOS. IEEE Transactions on Geoscience and Remote Sensing, n.32, 1994, p.897-905.
JENSEN, J. R. Introductory digital image processing: A remote sensing perspective. Prentice-Hall, Upper Saddle River, NJ, p.318, 1996.

JONES, B. A.; RITTERS, K. H.; WICKHAM, J. D.; TANKERSLEY, J.R.; O'NEILL, R. V., CHALOUD, D.J.; SMITH, E.R.; NEALE, A.C. An ecological assessment of the United States mid-Atlantic region: A landscape atlas. U.S. Environmental protection Agency, Report No. EPA/600/R-97/130, U.S. Printing Office, Washington, DC, 1997, p.104.

JUNG, M.; CHURKINA, G.; HENKEL, K. Exploiting synergies of global land cover products for carbon cycle modeling. Remote Sensing of Environment, n.101, 2006, p.534-553.

JUSTICE, C. et. al. The Moderate Resolution Imaging Spectroradiometer (MODIS): Land remote sensing for global change research. IEEE Transactions on Geoscience and Remote Sensing, n.36, 1998, p. 1228-1249.

KRUSE, F. A. Use of Airborne Imaging Spectrometer data to map minerals associated with hydrothermally altered rocks in the Northern Grapevine Mountains, Nevada and California. Remote Sensing of Environment, 24(1), 1988, p. 31-51.

KUMAR, L.; SCHMIDT, K.S.; DURY, S.; SKIDMORE, A.K. Review of hyperspectral remote sensing and vegetation science. In: MEER van der F. D., JONG de S. M. (Ed.). Imaging Spectrometry: Basic Principles and Prospective Applications. Kluwer Academic Press, Dordrecht, 2001, pp.111-155.

LAMBIN, E. F.; TURNER, B. L.; HELMUT, J. The causes of land-use and land-cover change: Moving beyond the myths. Global Environmental Change, n.11, 2001, p.261-269.

LIU, H.Q.; HUETE, A.R. A feedback based modification of the NDV I to minimize canopy background and atmospheric noise. IEEE Transactions on Geoscience and Remote Sensing, n.33, 1995, p.457-465. 
LUNETTA, R.L., JOHNSON, D.M.; LYON, J.G.; CROTWELL, J. Impacts of imagery temporal frequency on land-cover change detection monitoring. Remote Sensing of Environment, 89(4), 2004, p.444454.

LUNETTA, R.S.; ALVAREZ, R.; EDMONDS, C.M.; LYON, J.G.; ELVIDGE, C.D.; BONIFAZ, R. An assessment of NALC/Mexico land-cover mapping results: Implications for assessing landscape change. International Journal of Remote Sensing, 23(16), 2002, p. 3129-3148.

LUNETTA, R.S.; EDIRIWICKREMA, J.; JOHNSON, D.M.; LYON, J.G.; MCKERROW, A. Impacts of vegetation dynamics on the identification of land-cover change in a biologically complex community in North Carolina USA. Remote Sensing of Environment, n.82, 2002a, p. 258-270.

LUNETTA, R. S.; KNIGHT, J.F.; EDIRIWICKREMA, J.; LYON, J.G.; WORTHY, L.D. Land-cover change detection using multi-temporal MODIS NDVI data. Remote Sensing of Environment, n.105, 2006, p.142-154.

MACLEOD, R.D.; CONGALTON, R.G. A quantitative comparison of change detection algorithms for monitoring eelgrass from remotely sensed data. Photogrammetric Engineering \& Remote Sensing, 64(3), 1998, p.207-216.

MAHMOODZADEH, H. Digital change detection using remotely sensed data for monitoring green space destruction in Tabriz. International Journal of Environmental Research, 1(1), 2007, p.35-41.

MARCUS, W. A. Mapping of stream microhabitats with high spatial resolution hyperspectral imagery. Journal of Geographical Systems, n.4, 2002, p.113126.

MCWIRE, K.; MINOR, T.; FENSTERMAKER, L. Hyperspectral mixture modeling for quantifying sparse vegetation cover in arid environments. Remote Sensing of Environment, n.72, 2000, p.360- 374.
MODIS. MODIS Vegetation Index (MOD 13): Algorithm Theoretical Basis Document Page 26-29 (version 3), 1999. URL:http://modis.gsfc.nasa.gov/data/atbd/ atbd_mod13.pdf. Accessed on December 04, 2008.

NRC. Global Environmental Change: Research Pathways for the Next Decade. National Research Council, National Academy Press, Washington, DC. 1999. URL: http://www.nap.edu/openbook. php?isbn=0309064201. Assessed on September 10, 2011.

PRENZEL, B. Remote sensing-based quantification of land-cover and land-use change for planning. Progress in Planning, n.61, 2004, p.281-299.

RONDEAUX, G. ; STEVEN, M. ; BARET, F. Optimization of soil-adjusted vegetation indices. Remote Sensing of Environment, n.55, 1996, p.95-107.

ROUSE, J.W.; HAAS, R.H.; SCHELL, J. A.; DEERING, D.W. Monitoring vegetation systems in the Great Plains with ERTS. Third ERTS Symposium, Proceedings... NASA SP-351 I: 309-317. 1973

SCHOWENGERDT, R. A. Techniques for image processing and classifications in remote sensing. First Edition, Academic Press, USA. p.48-71. 1983.

SCHOWENGERDT, R. A. Remote Sensing: Models and methods for image processing. Third Edition, Academic Press, USA, p.98-124. 2006.

SCHROEDER, T. A.; CANTY, M.J., YANG, Z. Radiometric correction of multi-temporal Landsat data for characterization of early successional forest patterns in western Oregon. Remote Sensing of Environment, n.103, 2006, p.16-26.

SINGH, A. Review Article: Digital change detection techniques using remotely sensed data. International Journal of Remote Sensing, n.10, 1989, p.989-1003.

SOLAIMANI, K.; SHOKRIAN, F.; TAMARTASH, R.; BANIHASHEMI, M. Landsat ETM+ Based Assessment of Vegetation Indices in Highland Environment. 
Journal of Advances in Developmental Research, 2(1), 2011, p.5-13.

TRISHCHENKO, A. P.; CIHLAR, J.; LI, Z. Effects of spectral response function on surface reflectance and NDVI measured with moderate resolution satellite sensors. Remote Sensing of Environment, n.81, 2002, p.1-18.

TUCKER, C. J. Red and photographic infrared linear combinations for monitoring vegetation. Remote Sensing of Environment, n.8, 1979, p.127-150.

USGS. Earth Resources Observation and Science Center. 2008. URL: http://glovis.usgs.gov/ Accessed on December 04, 2008.

USGS. What is NDVI? United States Geological Survey: Science for Changing World. 2010. URL: http:// ivm.cr.usgs.gov/. Accessed on September 10, 2011.

WAN, Z. MODIS Land-Surface Temperature products users' guide. 2003. URL: http://www.icess.ucsb. edu/modis/LstUsrGuide/usrguide.html. Accessed on September 07, 2011.

WESSELS, K.; STEENKAMP, K.; MALTITZ, VON G.; ARCHIBALD, S. Remotely sensed vegetation phenology for describing and predicting the biomes of South Africa. Applied Vegetation Science, 14(1), 2011, p.49-66 (doi: 10.1111/j.1654-109X.2010.01100.x)

XIAO, X. M., ZHANG, Q.; BRASWELL, B. Modeling gross primary production of temperate deciduous broadleaf forest using satellite images and climate data. Remote Sensing of Environment, n.91, 2004, p. 256-270.

XIE, Y. Remote sensing imagery in vegetation mapping: A review. Journal of Plant Ecology, 1(1), 2008, p.9-23 (doi: 10.1093/jpe/rtm005)

ZHENG, C.H.; ZENG, C.S.; CHEN, Z.Q. A study on the changes of landscape pattern of estuary wetlands of the Minjiang river. Wetland Science, n.4, 2006, p.29-34.
ZORAN M, ANDERSON E (2006). The use of multi-temporal and multi-spectral satellite data for change detection analysis of the Romanian Black Sea coastal zone. Journal of Optoelectronics and Advanced Materials, 8(1): 252-256. 